\title{
Antibacterial behaviour of Common Winter Season Weeds on Human Pathogens in Doon Valley, Uttarakhand, India
}

\author{
Maneesha Singh ${ }^{1}$, Rashmi Bist $^{2}$ \\ ${ }^{1}$ Assistant Professor, Department of Life Sciences, Shri Guru Ram Rai Institute of Technology and Science, Patel Nagar, Dehradun
} (248001)

${ }^{2}$ Department of Life Sciences, Shri Guru Ram Rai Institute of Technology and Science, Patel Nagar, Dehradun (248001), Uttarakhand, India

\begin{abstract}
Weeds are plants which over dominate others by abundance, growth, and coverage, thus disturbing of ecosystems. Weeds are adapted well to grow in both unfavourable and favourable environments and cause yield and quality loss, competing with crops for resources. The resistance behaviors against microbial diseases promote us to find the antimicrobial behavior of weeds grown in Dehradun during winter season against common pathogens. Out of the twelve extracts assayed, the extract of Euphorbia helioscopia was most active against all the studied bacterial strains. Therefore, Minimum Inhibitory Concentration (MIC) of this extract was determined against the selected bacteria. The MIC for different strains is $62.5 \mathrm{mg} / \mathrm{ml}$. Besides having antimicrobial activities, plants also be used as a source of anti diabetic and antioxidant potential due to presence of glycosides, tri terpenoids etc.
\end{abstract}

Keywords: Antibacterial activity; Weeds; Pathogens, Minimum inhibitory concentration

\section{Introduction}

Plants, since ancient times have been utilized as a source of nutrition and healthcare products. Plants are a reservoir of diverse kinds of bioactive chemical agents and have often been utilized either in the form of traditional preparations or as pure active principles. It is reasonable to make use of locally available plants, domesticated or wild, that could substitute the synthetic preparations. The healing powers of traditional herbal medications have been validated by various workers. The use of herbs as complementary and alternative medicine has increased dramatically in the last 20-25 years [1]. Moreover, emergence of multiple drug resistant strains of microorganisms due to indiscriminate use of antibiotics has generated a renewed interest in herbal medicines [2].

Weeds, commonly defined as a plants that grows out of place and are competitive, persistent and pernicious $[3,4]$, have been a part of civilization and many ancient documents mention about humans battling weeds in the crop fields. In a broad sense, weeds are plants which over dominate others by abundance, growth and coverage, thus disturbing the balance of ecosystems [4, 5]. Due to their inherent efficiency in nutrient uptake and use, weeds easily invade disturbed lands, adversely affecting ecosystems and also disturb/reduce natural phyto - diversity. Weeds are adapted well to grow in both unfavourable and favourable environments and cause yield and quality loss, while competing with crops for resources $[6,7]$.

Weeds are also found to be resistance to most of the microbial disease when compared to the crops which shows disease symptoms. This antimicrobial behavior is associated with production of various allelopathic interactions. Different types of allelochemicals (secondary compounds) may act as the eco friendly agrochemicals useful as fungicide, pesticide, and herbicides.
Moreover, modern medicine is becoming more widespread but at a high cost. In rural areas, it is useful in certain cases, like surgery, but traditional medicine still plays an important role and is commonly used as primary form of health care for people especially in critical cases such as, in postpartum women, A number of plant species have been used in traditional medicine to treat inflammations, bronchitis, cold, and infections or as a diuretic, antipyretic, analgesic, emetic etc. Considering the aforesaid, it is assumed that the need of the hour is to search for new antimicrobials [8-12]. Keeping in view above biological activities and resistance behavior against microbial diseases promote us to find the antimicrobial behavior of weeds grown in Dehradun, India during winter season associated with crops like wheat and mustard.

\section{Material and Methodology}

\subsection{Materials}

The material for the present study comprised of whole plants of common weeds of Dehradun such as Anagallis arvensis L., Capsella bursa-pastoris (L.)Medik., Chenopodium album L., Euphorbia helioscopia L., Fumaria indica (Hausskn.) Pugsley, Gnaphalium canescens, Plantago major L., Ranunculus sceleratus L., Rumex nepalensis L., Saussurea heteromalla, Silene conoidea (L.), Stellaria media(L.)Vill. that grows in association with winter crops like wheat and mustard in Dehradun, Uttarakhand, India.

\subsection{Collection and processing of plant samples}

The fresh whole plants were collected from different places of Doon valley, Uttarakhand, India. The plant samples were dried in shade at $25^{\circ} \mathrm{C}$ to $35^{\circ} \mathrm{C}$ for $15-20$ days in the laboratory and then crushed to coarse powder using grinder. The dried plant material was stored in paper bags. 


\section{International Journal of Science and Research (IJSR) \\ ISSN (Online): 2319-7064}

Index Copernicus Value (2015): 78.96 | Impact Factor (2015): 6.391

The dried plant materials powder was subjected to diffusion extraction with ethanol solvent. About $50 \mathrm{gm}$ accurately weighed dry plant samples powder were extracted with $200 \mathrm{ml}$ of respective solvent in a closed flask and allowing it to stand for 48 hours. After the extraction process, the filtrates were separated by filtration and the solvent were evaporated using water bath. The extract was then transferred to previously weigh air tight container, (weighed on an electronic balance), percentage yield of the crude extracts were calculated and stored in refrigerator until they were screened for the antibacterial activity.

\subsection{Source of Bacterial Cultures}

The antibacterial assay of different extracts of studied plants were performed against four bacterial strains. All the bacterial strains were procured from the Department of Microbiology, S.G.R.R.I.T.S., Dehradun, Uttarakhand. The study was carried out at the Microbiology laboratory in Department of Life Sciences, S.G.R.R.I.T.S, Dehradun, Uttarakhand, India.

\subsection{Evaluation of the Antibacterial Potential of Plants Extracts}

A total of four bacterial strains i.e. two gram positive viz. Staphylococcus epidermidis, Staphylococcus aureus and two gram negative bacteria viz. Salmonella typhimurium, Pseudomonas aeruginosa were taken to evaluate antibacterial potential of the different extracts of weeds. The bacterial cultures were maintained on normal nutrient agar slants that were stored at $4^{0} \mathrm{C}$.

\subsection{Antibacterial Screening}

Antibacterial activity was demonstrated using disc diffusion method [5]. A pure colony of each of the test bacterial strains were sub cultured into $5 \mathrm{~mL}$ of nutrient broth using inoculating loop followed by incubation at $37^{\circ} \mathrm{C}$ for $3-4$ hours. The dried extracts were dissolved in dimethyl sulfoxide (DMSO) and subjected to preliminary antibacterial screening with the concentration of $500 \mathrm{mg} / \mathrm{ml}$ to know whether they were active against the particular bacteria or not. $0.1 \mathrm{ml}$ of inoculums was spread on the solidified Muller Hinton agar surface. For screening of active extracts, sterile $6 \mathrm{~mm}$ diameter whatman No. 41 filter paper discs were dipped in the plant extracts and then placed carefully onto the Muller Hinton agar media against the studied bacterial strains. The results were recorded by measuring the zones of growth inhibition surrounding the disc. Clear inhibition zones around the discs indicate antibacterial activity.

Further, Minimum Inhibitory Concentration (MIC) value of only active extracts were determined against those bacterial strains which showed high sensitivity during the preliminary antibacterial testing. It was performed by serial dilution of the active concentrated extract in pure DMSO to achieve a decreasing concentration range of $500 \mathrm{mg} / \mathrm{ml}$ to $31.25 \mathrm{mg} / \mathrm{ml}$. The sensitivities of all the bacterial strains were also observed against the standard drug such as streptomycin and against DMSO to set them as a positive and a negative control, respectively.

\section{Result and Discussion}

Weeds are commonly grown among the cultivated plants, may be used for food or medicinal purposes viz., Portulaca oleracea L. and Mentha spicata L. are examples among a great many others, as they not create any side effect to the human's body while chemical based antibiotics does so. In the same direction studies was conducted by various scientist such as Bhuvaneswari et al. (2011), Bhattarai \& Shreshta, (2009), Kannan and Kulandaivelu (2007), Kumar Samy et al., (2002), Parekh et al., (2005), Singh et al., (2013), Uday Prakash, (2011) [8,9,10,11,12,13,14]on comparison of antimicrobial activities of weeds such as Withania, Eupatorium etc. and have claimed that the antimicrobial activity might have been observed due to the presence of strong inhibitory allelochemicals present in these invasive weeds. These compounds exhibit interesting biological properties, such as phytotoxic, antimicrobial, antifungal, and insecticidal properties. These chemicals, in addition to a wide variety of related compounds, are involved in their metabolism, detoxification mechanisms, and degradation on crop soils and other systems [15].

The present study was an effort to investigate and validate the important above mentioned potentials of the weeds in regards to determine the antibacterial activity of common winter season weeds of Doon Valley, Uttarakhand.

\subsection{Nature and yield of crude extracts}

Different quantities of the powdered plants material were subjected to solvent extraction. The extracts were concentrated on water bath and they were finally reduced to dryness to get dry extracts. The maximum percentage of crude extract yield is obtained in Stellaria media $(10.70 \%)$ followed by Plantago major (7.734\%) (Table1).

Table 1: Yield of crude extracts of weeds from ethanol solvent

\begin{tabular}{|c|c|c|}
\hline Weed plants & $\begin{array}{c}\text { Weight of } \\
\text { extract } \\
\text { (gm) }\end{array}$ & $\begin{array}{c}\text { Percentag } \\
\text { e } \\
\text { Yield (\%) }\end{array}$ \\
\hline Anagallis arvensis L. & 2.45 & 5.34 \\
\hline Capsella bursa pestoris (L.) Medik. & 1.17 & 4.87 \\
\hline Chenopodium album L. & 1.82 & 3.63 \\
\hline Euphorbia helioscopia L. & 3.18 & 6.35 \\
\hline Fumaria indica(Hausskn.)Pugsley & 2.26 & 6.84 \\
\hline Gnaphalium canescens & 2.24 & 4.48 \\
\hline Plantago major L. & 1.27 & 7.74 \\
\hline Ranunculus sceleratus L. & 1.02 & 2.04 \\
\hline Rumex nepalensis L. & 1.14 & 4.90 \\
\hline Saussurea heteromalla & 2.17 & 4.33 \\
\hline Silene conoidea (L.) & 0.69 & 3.01 \\
\hline Stellaria media (L.) Vill. & 2.03 & 10.7 \\
\hline
\end{tabular}




\section{International Journal of Science and Research (IJSR) \\ ISSN (Online): 2319-7064 \\ Index Copernicus Value (2015): 78.96 | Impact Factor (2015): 6.391}

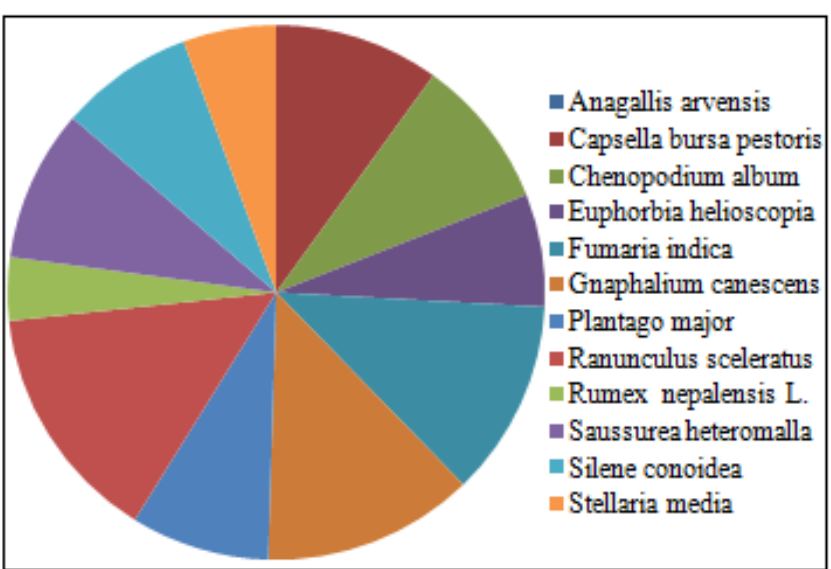

Figure 1: Comparative analysis of percentage yield of crude extract of weeds of winter season

\subsection{Antibacterial Assay}

All the twelve extracts of plants showed antibacterial activity against all the studied bacterial strains that are pathogenic to human beings causing several diseases such as pneumonia, food poisoning, urinary tract infections, meningitis, fever etc. Among the extracts assayed, Euphorbia helioscopia were found to be most active that exhibit antibacterial activity against all bacterial strains. In contrast to this, all plant extracts exhibited highest activity against Pseudomonas aeruginosa followed by
Staphylococcus aureus among all the studied bacterial strains (Table 2). While Coban and Biyik (2010) [16] has reported antibacterial activities of Ranunculus agains various bacterial strains and found higher antibacterial activity as comparison to others.

Table 2: Zone of inhibition (mm) of plant extracts against the bacterial strains

\begin{tabular}{|l|c|l|l|c|}
\hline \multirow{2}{*}{ Weed Plants } & \multicolumn{4}{|c|}{$\begin{array}{c}\text { Zone of inhibition (in mm ) } \\
\text { against }\end{array}$} \\
\cline { 2 - 5 } & $S E$ & $S A$ & $S T$ & $P A$ \\
\hline Anagallis arvensis L. & 1 & 2 & 1 & 8 \\
\hline $\begin{array}{l}\text { Capsella bursa pestoris (L.) } \\
\text { Medik. }\end{array}$ & 8 & 2 & 1 & 7 \\
\hline Chenopodium album L. & 1 & 7 & 1 & 9 \\
\hline Euphorbia helioscopia L. & 9 & 7 & 8 & 15 \\
\hline $\begin{array}{l}\text { Fumaria indica } \\
\text { (Hausskn.)Pugsley }\end{array}$ & 1 & 2 & 1 & 8 \\
\hline Gnaphalium canescens & 3 & 1 & - & 7 \\
\hline Plantago major L. & 1 & 1 & 1 & 9 \\
\hline Ranunculus sceleratus L. & 1 & 9 & 1 & 10 \\
\hline Rumex nepalensis L. & 3 & 2 & 1 & 8 \\
\hline Saussurea heteromalla & 9 & 7 & 1 & - \\
\hline Silene conoidea (L.) & 1 & 3 & 1 & 10 \\
\hline Stellaria media(L.) Vill. & 2 & 9 & 8 & 11 \\
\hline
\end{tabular}

Disc Diameter: 6mm (included)

Note: *SE: Staphylococcus epidermidis; SA: Staphylococcus aureus; ST: Salmonella typhimurium; PA: Pseudomonas aeruginosa

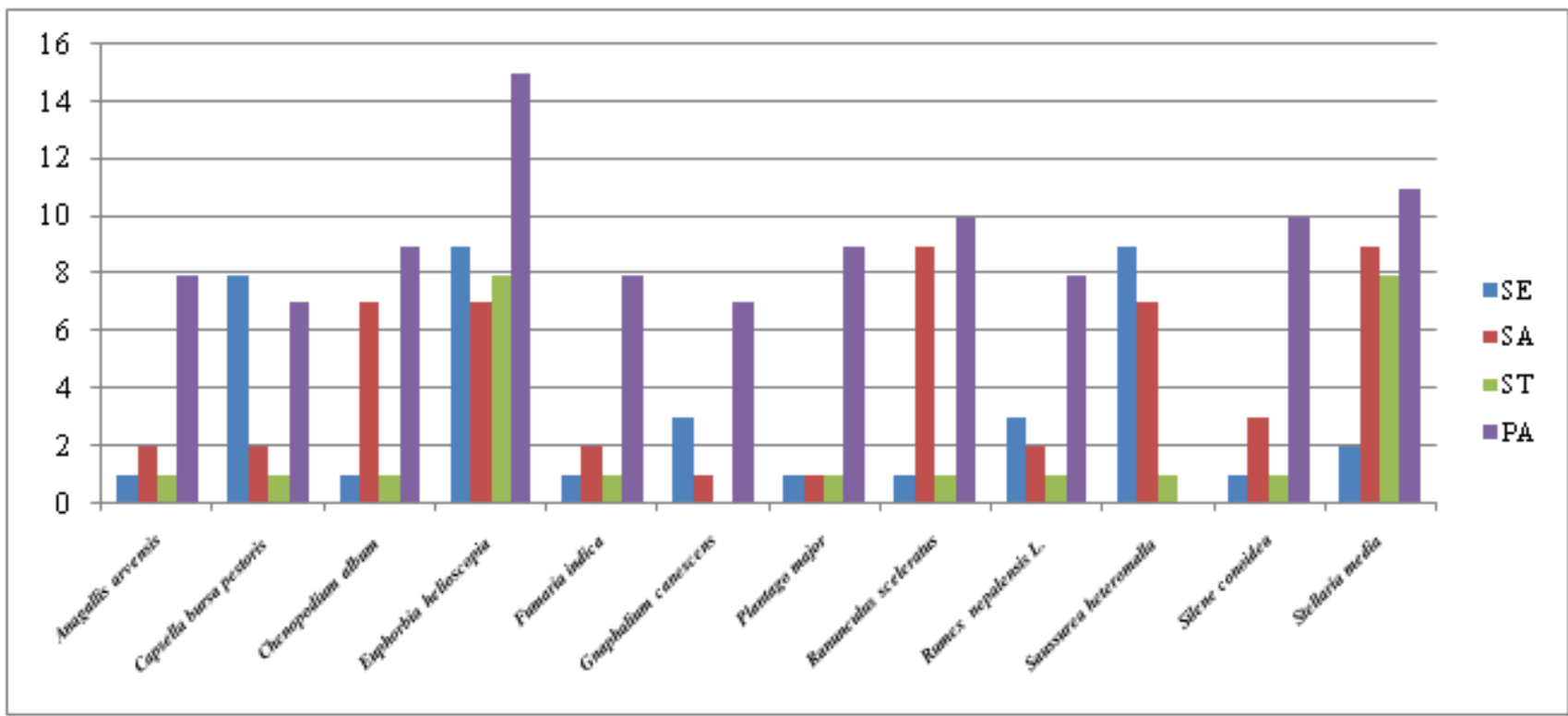

Figure 2: Comparative analysis of zone of inhibition of plant extracts against four bacterial strains

Out of the twelve extracts assayed, the extract of Euphorbia helioscopia was most active against the studied one Gram negative and two Gram positive bacterial strains. The maximum zone of inhibition obtained during the preliminary screening for extract was $15 \mathrm{~mm}$ against Pseudomonas aeruginosa, $7 \mathrm{~mm}$ against Staphylococcus aureus, $8 \mathrm{~mm}$ against Salmonella typhimurium and $9 \mathrm{~mm}$ against Staphylococcus epidermidis. Therefore, Minimum Inhibitory Concentration (MIC) of this extract was determined against the selected bacteria (Table 3).

\subsection{Minimum inhibitory concentration (MIC) analysis}

Minimum inhibitory concentration is important in diagnostic laboratories to confirm resistance of microorganisms to an antimicrobial agent and also to monitor the activity of new antimicrobial agents. A lower MIC is an indication of a better antimicrobial agent [17]. An MIC is generally regarded as the most basic laboratory measurement of the activity of an antimicrobial agent against an organism [18]. MIC analysis was performed by serial dilution of the concentrated ethanol extract in pure DMSO to achieve a decreasing concentration range of $500 \mathrm{mg} / \mathrm{ml}$ to $62.5 \mathrm{mg} / \mathrm{ml}$. 


\section{International Journal of Science and Research (IJSR) \\ ISSN (Online): 2319-7064 \\ Index Copernicus Value (2015): 78.96 | Impact Factor (2015): 6.391}

On performing MIC analysis for the Euphorbia helioscopia extract, the results revealed that all the selected bacterial strains i.e. Pseudomonas aeruginosa were sensitive against the $62.5 \mathrm{mg} / \mathrm{ml}$ concentration of the extract, thereby exhibiting $62.5 \mathrm{mg} / \mathrm{ml}$ as their MIC value except Staphylococcus epidermidis, and Staphylococcus aureus, Salmonella typhimurium that were sensitive against the $250 \mathrm{mg} / \mathrm{ml}$ concentration of the extract whose MIC was $250 \mathrm{mg} / \mathrm{ml}$ (table-3). In order to check the susceptibility of bacterial strains ready to use antibiotic impregnated disc i.e. Streptomycin was used as a positive control. All of them showed clear zones of inhibition around the disc interpreting their high sensitivity towards antibiotic. In contrast to this, DMSO (99\% pure) was used as a negative control against which none of the bacterial strains showed zone of inhibition revealing resistance of cultures towards DMSO (table-4).

Table 3: Minimum Inhibitory Concentration (MIC) of Euphorbia helioscopia extract

\begin{tabular}{|c|c|c|c|c|}
\hline \multirow{2}{*}{ Bacterial Strains } & \multicolumn{5}{|c|}{ Zone of Inhibition in $\mathrm{mm}$} \\
\cline { 2 - 6 } & $\begin{array}{c}500 \\
\mathrm{mg} / \mathrm{ml}\end{array}$ & $\begin{array}{c}250 \\
\mathrm{mg} / \mathrm{ml}\end{array}$ & $\begin{array}{c}125 \\
\mathrm{mg} / \mathrm{ml}\end{array}$ & $\begin{array}{c}62.5 \\
\mathrm{mg} / \mathrm{ml}\end{array}$ \\
\hline Staphylococcus epidermidis & 9 & 7 & - & - \\
\hline Staphylococcus aureus & 7 & 4 & - & - \\
\hline Salmonella typhimurium & 8 & 5 & - & - \\
\hline Pseudomonas aeruginosa & 15 & 13 & 10 & 7 \\
\hline
\end{tabular}

Table 4: Zone of inhibition ( $\mathrm{mm}$ ) of positive and negative control against the bacterial strains

\begin{tabular}{|c|c|c|}
\hline Bacterial Strains & $\begin{array}{c}\text { Negative } \\
\text { Control: } \\
\text { Streptomycin }\end{array}$ & $\begin{array}{c}\text { Positive } \\
\text { control: } \\
\text { DMSO }\end{array}$ \\
\hline Staphylococcus epidermidis MTCC-5615 & $20 \mathrm{~mm}$ & - \\
\hline Staphylococcus aureus MTCC-737 & $24 \mathrm{~mm}$ & - \\
\hline Salmonella typhimurium MTCC-1255 & $26 \mathrm{~mm}$ & - \\
\hline Pseudomonas aeruginosa ATCC-424 & $25 \mathrm{~mm}$ & - \\
\hline
\end{tabular}

Disc Diameter: $6 \mathrm{~mm}$ for positive and negative control (included).

\section{Conclusion}

The present study was carried out on the antibacterial activity of common winter season weeds in Doon valley against the pathogenic bacterial strains. Out of the twelve extracts assayed, the extract of Euphorbia helioscopia was most active against all the studied Gram negative and Gram positive bacterial strains. Therefore, Minimum Inhibitory Concentration (MIC) of this extract was determined against the selected bacteria. The MIC value for Pseudomonas aeruginosa is $62.5 \mathrm{mg} / \mathrm{ml}$ whereas for Staphylococcus epidermidis, and Staphylococcus aureus, Salmonella typhimurium $250 \mathrm{mg} / \mathrm{ml}$. In future the plant extract of weeds could be exploited to control various bacterial infections as plant extracts revealed the presence of various phytoconstituents such as glycosides, tri terpenoids, flavanoids etc.

\section{References}

[1] Jimoh FO, Adedapo AA, Afolayan AJ: Comparison of the nutritive value, antioxidant and antibacterial activities of Sonchus asper and Sonchus oleraceus. Rec Nat Prod 2011, 5(1): 29-42.
[2] Chopra I, Hodgson J, Metcalf B, Poste G: The search for antibacterial agents effective against bacteria resistant to multiple antibiotics, Antimicrob Agents Chemother 1997, 4: 497-503.

[3] James L and Evans JO: Noxious Range Weeds, West view Press, Boulder, CO, USA, 1991.

[4] Wittenberg, R. \& M. J. W. Cock. 2001. Invasive alien species: A toolkit of best prevention and management practices. CABI Publication, Oxon, London.

[5] Dulger B \& Ugurlu E: Evaluation of antimicrobial activity of some endemic Scrophulariaceae members from Turkey. Pharmaceutical Biology 2005, 43(3): 275-279.

[6] Borkataky M, Kakoty B B, Lakhi Ram Saikia: Antimicrobial Activity and Phytochemical Screening of Some Common Weeds of Asteraceae Family. Int. J. Pharm. Sci. Rev. Res 2013, 23(1): 116-120.

[7] Westbrooks RG: Invasive Plants, Changing the Landscape of America: Fact Book. Washington,Federal Interagency Committee for the Management of Noxious and Exotic Weeds, 1998. 109.

[8] Bhattarai N and Shrestha G: Nepal journal of science and technology 2009, 10: 91-95.

[9] Kumarasamy Y, Fergusson ME, Nahar L and Sarker SD: Bioactivity of Moschamindole from Centaurea moschata. Pharmaceutical Biology, 2002,40(4): 307 - 310, ISSN 1388-0209.

[10] Parekh, J, Nair, R and Chanda, S: Preliminary screening of some folkloric plants from Western India for potential antimicrobial activity. Indian J. Pharmacol. 2005, 37: 408409.

[11] Singh M, Walia S, Singh AK: Phytochemical characterization and antibacterial activity of Lindenbergia indica Vatke: A common wall flora against some human pathogens in Doon Valley, Uttarakhand. Indian J. of Natural Products and Resources. 2013, 4(2): 138-145.

[12] Udaya Prakash NK, S Bhuvaneswari, R Aravind, V Kaviyarasan, H Sekarbabu, A comparative study on antibacterial activity of common weeds. Int $J$ Pharm Bio Sci, 2011, 2 (1): 677-683.

[13] Bhuvaneswari S, Aravind R., Kaviyarasan V, Kalaivanan $\mathrm{K}$ and Sekar Babu Hariram: A comparative study on antibacterial activity of Common Weeds. International Journal Of Pharma and Bio Sciences2(1)679-683.

[14] Kannan ND and Kulandaivelu G: Allelopathy Journal.2007, 20 (1), 213-220.

[15] Duke SO and Oliva A. In: Macias et al. (Eds.) Allelopathy: chemistry and mode of action of allelochemicals.(CRC Press, LLC, Florida, USA). 2004, 201-216.

[16] Coban EP and Biyik H (2010). Anti microbial activity of the ethanol extracts of some plants natural growing in Aydin Turkey. Afr. J. Microbiol. Res., 4: 2318-2323.

[17] Andrews J M: Determination of Minimum Inhibitory Concentrations. Journal of Antimicrobial Chemotherapy, 2001, 48 (Suppl. 1): 5-16.

[18] Turnidge JD, Ferraro MJ \& Jorgensen JH, Susceptibility test methods: general considerations. In P.R. Murray, E.J. Baron, J.H. Jorgensen, M.A. Pfaller, R.H. Yolken. Manual of Clinical Microbiology. 8th Ed. Washington. American Society of Clinical Microbiology. 2003, 1103. 